\title{
Hoeveel Kerkbegrippe is by Ons in Swang?
}

'n Paar inleidende opmerkinge sal hicr gepas wees.

1. As nié-kerkregkundige sal ek nogtans probeer om nie onkerkregkundig te wees nie.

2. Dit gaan hier oor kerkbegrippe wal daar by .ons', teolö i.c. Gereformeerdes. in Suid-Afrika. voorkon. en dus nie oor alle moontlike kerkbegrippe nie (bv. Roomse. L.utherse ens.), al kon dit wel sydelings ter sprake.

3. My persoonlike belangstelling vir hierdie onderwerp vloei voort uit die interkerk(verbande)like gesprek van die (icref. Kerk Johannesburg-Sentraal en die N. (j. Kerke Iohanneshurg en Iohannesburg-()os. Dit is gewoonlik so dat 'n skerp konfrontasie met in ander kerkbegrip(pe) dwing tot skerper formulering van die eie (Bybelse) standpunt.

\section{BYBEL SE KERKBEC}

Met .Bybelse kerkbegrip' word bedoel: wat is die kerk volgen: Skriftuurlike siening? Dit suggereer weliswaar die onnoonllike moontlikheid van ' $n$ ander kerkbegrip(pe) as die Bibelse kerkbegrip.

Hieroor wil ons nie breed uitwei nie, nié onklat dit nie van fundamentele betekenis sou wees nie. inteendeel!, maar omdat daar by ons (Gereformeerde teoloë) prinsipieel algehele eenstemmigheid bestaan oor wat die kerk is - al slaag ons. jammerlik genoeg. nie in die praktyk daarin om die prinsipiële standpunt konsekwent te handhaaf nie. Prof. W. J. Snyman het al in 1959 te Rustenberg 'n waarskuwende woord laat hoor: "Ons kerkhegrip moet gereformeer word, anders $\mathrm{kom}$ die' kerk op 'n verkeerde spoor".' Op die waarheid van hierdie woorde kom ons weldra terug.

Eksegete is dit daaroor redelik eens dat die woord .ekklesia' in die N.T. voorkom in slegs tweeerlei betekenis. en wel as lokale ckklesia en totale ekklesia (gemeente). (In die Septuaginta word die kahal JIVII - meesal - met ekklesia vertaal). (Oor die vraag of ons die woorde .kerk' (.kuriake', wat ons nié in die N.T. aantref nie) en gemeente' (ekklesia') as sinonieme moet gebruik. is daar verskil van opinic." Trouens, die afkoms van die woord .kerk' is onseker. Hans kïng meen dat dit afkomstig is van die bisantynse volksvorm .kyrike'. en dat die romaunse tale in teenstelling met germaanse tale die regstreekse verband met die N.Te woord .ekklesia' bewaar gehou het. .. Het latijnse ecclesia, het spaanse iglesia, het franse église. het italiaanse chiesa zijn alle afkomstig van het griekse ekklesia"." Indien ons egter nie in "n Babiloniese spraakverwarring vasgevang wil raak nie. moel ons n.i die woorde gemeente' en ,kerk' as sinonieme grebruik en geensins pratat van 'n ,kerk" wat uit 'n aantaal gemeentes' bestaan nie.' Albei woorde 
Ului op die Messiaanse (jodsvolk in sy totaliteit en lokaliteit. Ons kan dus ook spreek van die totale kerk en die lokale kerk.

In Matt. 16:18 het ons te doen met die tòtale gemeente (kerk), in Matt. 18:17 met die lokale gemeente (kerk) - die enigste twee kere dat die Here Jesus van die gemeente' gespreek het. In die briewe van Paulus kom veral in Efesiërs en Kolossense die gedagte van die totale gemeente" skerp na vore. terwyl in sy ander briewe (veral Romeine en I Korinthiërs) die .lokale gemeente' in die gesigsveld tree "Nêrens in die N.T. word 'n groép gemeentes (kerk) met die versamelnaam gemeente (kerk) (enkelvoud) aangedui nie. maar steeds in dic meervoud as gemeentes (vgl. Rom. 16:4, 16; 1 Kor. 11:16. 14:33; II Kor. 8:18. 11:8, 12:13: Gal. 1:2. 22: I Thess. 2:14). Aldus is elke lokale gemeente 'n openbaring van die totale gemeente en nie in déél van die groot kerk" nie. "De plaatslijke kerk is niet een sectie of .provincie' van de totale ekklesia. $Z c$ is geenzins een onderafdeling van de eigenlijke .kerk'...." (jevolglik is dit ook ..geen goede gewoonte om alleen de totale ckklesia kerk" te noemen .." Nee. ...je plaatselijke kerk hehoort niet alleen tot de kerk. De plaatselijke kerk is kerk. Slechts vanuit de plaatselijke kerk en haar concrete voltrekking kan de totale kerk begrepen worden". Daarom moet ons onthou dat die totale kerk nie "n ..daneensluiting" of ..associatie" is van plaaslike kerke nie.". .Kerk is niet een overkoepelend orgaan van afzonderlijke gemeenten. Niet een optelsom van afzonderlijke ekklesia's heeft als uitkomst de ekklesia: de ckklesia valt niet uiteen in de afzonderlijke ekklesia's. Maar op verschillende plaatsen is de ekklesia van God". Daarom bestaan die (Ciereformeerde) kerk nie uit ' $n$ aantal gemeentes nie (dit sou 'n toutologie wees) ntaar uit gelowiges wat om getal- en taalredes afsonderlike" gemeentes kerke vorm.'

Die enigste uitsondering skyn Hand. 9:31 te wees. omdat dit hier lyk asof gemeente bestaan uit 'n áántal gemeentes. Hierteenoor kan gestel word: (a) moontlik was daar destyds net één gemeente: (b) daar is 'n teksvariant: (c) dit is die enigste pleh in die N.T. waar so 'n aanduiding voorkom.

Ons Belydenisskrifte is ook baie duidelik oor wat die kerk is. ..Ons glo en bely in enige katolieke of algemene Kerk wat in heilige vergadering is van almal wat waarlik in Christus glo, wat hulle hele saligheid in Jesus (hristus verwag en gewas is deur sy bloed. geheilige en verseël deur die Heilige (jees" (N.(j.B. art. 27). Die H.K. verklaar art. 9 van dic Apostolicum soos volg: ..Dat die Seun van (jod uit die ganse menslike geslag vir $\mathrm{Hom}$ in gemeente wat tot die ewige lewe uitverkies is, deur Sy ciees en Woord, in die eenheid van die ware geloof, van die begin van die wereld af $10 t$ aan die einde toe. vergader beskerm en onderhou: en dat ek daarvan "n lewende lid is en ewig sal bly" (antw. 54). I et daarop dat in die H.K. 'n oorgang van die .Kerk' (in rrag 54) na gemeente (in antwoord 54) gemaak word, in die Afrikunne vertaling altans. terwyl die N.(i.B. die woord .Kerk' (met hoofletter) gebruik.

Ons wil ten slotte hier hyvoeg dat die uitsprake oor die gemeente kerk as die volk van God". die ,liggaam van Christus" en die bou- 
werk' van die Heilige (jees' fom net die dric te noem) van toepassing gemaak word op sowel die lokale as totale gemeente/kerk.

\section{VAI.SE KERKBEG(IRIPPE.}

\section{STATIESE KERKBEGRIP}

Hierdie kerkbegrip is seker die flagrantste - en vulgêrste - van al die baie kerkbegrippe en byna nie nodig on selfs genoém te word nie. Ondat dit egter soveel maal voorkon by lidmate ì predikante. is dit log noodsaaklik om sout op hierdie slak te lê. En dan bedoel ons hier nie die valse dilemma van bewaar . . . vermeerder gemeenteopbou/sending nie, nee, ons bedoel daardie verwarrend-skeppende daaglikse spraakgebruik van. Ons gaan kerk toe'. Hier word die gebou en die gelowiges. al is dit op speelse maar tog baie konkrete wyse. geidentifiseer, of beter nog: deur hierdie spraakgebruik word die .gelowiges' van die ,kerk' gedistansieer: hulle moet dan kerk toe gáán. Ons weet almal: ons gaan (kerk) gebou toe, maar dit is verbysterend on te sien en te hoor van lidmate dat hulle Sondae en weeksdae moet kerk toe gáán. Hulle besef nie meer dat hulle die kerk/gemeen!e is nie. Vergelyk in hierdie verband ook: Ons gaan kerk bou'. en wat die Bybel onder .kerkbou' verstaan (Efes. 2:20-22). Dink aan visitasiereglemente met in vraag oor .kerkbesoek'.

Hierdie spraakgebruik van .kerk toe gaan verdien dus allermins aanheveling. Ons gaan die Here dien. Ons galan erediens hou.

\section{DINAMISTIESE KERKBEGRIP}

Ook in hierdic verband het ons nie die oog op die apostolats. teologie (Hoekendijk c.s.) met sy kerkbegrip van op-weg-wees, met sy identifisering van kerk en sending, van wat die kerk in sy wese is en wat sy roéping is (al is mèt die .wese onmiddellik óok die .roeping" gegee). nee. ons het dit hier ook maar weer oor 'n alledaagse by ons voorkomende spraakgebruik van . Ons gaan kerk hou'. Hier word die kerk beskryf in terme van die kultiese handeling, in terme van wat daar tydens 'n erediens gebeúr. Kerk is hier die aklualistiese, dimamistiese kerk. Tereg sê prof. Snyman dat as plaaslike vergadering van gelowiges ..beteken dit nie net 'n samekoms nie, maar ook iéts wat saamkom. en dus bestaan, al is dit nie juis saam nie. I Kor. 14:23. Dit is dus ' $n$ organisasie wat bestaan afgesien van die kultus."."

Die kerk is dus méér as net kultiese aktualiteit.

Terloops, Ridderbos wys daarop dat in die twee keer wat die apostel Paulus die woord ,erediens' gebruik, hy dit nié toepas op die gemeentelike samekomste nie maar op die daaglikse lewenswandel." Hy voeg by dat ekklesia by Paulus behalwe plaaslike en algemene kerk ook die betekenis van godsdienstige sumekoms kan hê (vgl. I Kor. 11:18. $14: 19,28,34,35) . "$ Indien Ridderbos se eksegese hier korrek is (en ekklesiai). sal ons moet toegee dat hierdic .kerkbegrip' nic so .vals" is nie. 


\section{HIPERSIATIESE KERKBEGIRIP}

Die kerk is nooit ..een boven de concrete mensen en hun beslissing zwevend superwezen", die kerk is nooit .zonder mensen"." Daarom kan die kerk nooit losgemaak word van die konkrete mense wat die kerk vorm en .verobjektiveer' word nie. selfs al is die kerk as gemeenskap meer as die som van die individue. Die kerk is 'n historie'se werklikheid en geen jdealistiese grootheid nie. ${ }^{13}$

By die hiperstatiese kerkbegrip funksionecr die kerk as platoniese idee, as abstrakte grootheid. Ons vind dit o.a. by J. A. Heyns -.- die titel van die boek verraai dit al -. in sy ...Klagteboek teen die Kerk en sy mense". want hy insinueer hiermee dat die .kerk iets anders is as sy mense". Hy praat van die kerk as die ... joddelike instelling" en hulle wat aan die kerk behoort"14 _.. asof die Goddelike instelling vir een enkele oomblik sonder mènse ingestel is en kan bestaan. Die kerk is sê ons N.G.B.. 'n heilige vergadering van almal wat waarlik in Christus glo (art. 27). (jod het nie eers die instelling' ingestel en toe die gelowiges Jaar ingelei nie. Die gelowiges is die kerk en die kerk is die gelowiges. Hierdie identifikasie is onuithaalbaar. Heyns opereer met die thomistiese vorm-materie-skema. Bowendie begaan liy 'n logiese denkfout deur die konnotasie van die begrip .kerk' le laat verander.

Hierdie gedagte is dieper ingeburger as wat ons vernoed. I ees ons die voorwoord van die ..Almanak" van 1966. dan hoor ons: .. Die kerk klop aau u deur!" En verder aan lui dit: ..In elke uitgawe kom dic (iereformeerde Kerk in Suid-Afrika na u toe". ${ }^{3}$ In die verhand verneen ons dikwels van bv. iemand wat van die N.G.K. na die G.K. wil oorgaan' of ek behoort tot die (j.K.' (. . ek behóort nie tot die kerk nie, maar wel aan Jesus Christus. H.K. Sondag I; ek is wel lidmáát van 'n kerk). Tog verraai hierdie woorde 'n valsheid, omdat ek nie lidmaat is van ' $n$ kerk nie of van ' $n$ aamtal kerke nie. maar van dié (N.G. of G.) kerk Kaapstad of Pretoria ens.

In hierdie verband kom ook die vereenselwiging voor van die kerk met die .onsigbare kerk'. Selfs Polman kon die saak. met verusysing na art. 27 N.G.B.. nic ophelder met sy dualistiese konklusie dat ..dit artikel ziet metterdaad voornamelijk op de onzichtbare kerk als mystieke lichaam van Christus, als vergadering der ware Christgelovigen. maar toch ook enigermate op de zichtbare kerk". ${ }^{\text {s }}$

\section{ORGANISIIESE KERKBEGRIPI'A}

Op voetspoor van veral Kuyper word daar onderskei tussen dic .kerk as organisme' en die .kerk as instituut'. Die vraag is of hierdie .onderskeiding' nie soveel inherente teenstrydighede bevat nie dat dit nie anders kan as om op 'in skeiding uit te loop nie. Prof. S. C. W. Duvenhage het in 'n mooi studie in pragtige uesensanalise van die kerk gemaak." Desondanks kom hy tot die volgende konklusie: .. Tot hierdie sigbare kerk behoort die Christelike huwelik, die Christelike gesin, die Christelike staat. dic (hristelike skool, die Christelike vereniging. die christelike herkinstituut ens. In hierdic samelewingsverbande kom 
die liggaam van Christus sigbaar tot openbaring". ${ }^{1}$ In in voctnoot op bls. 63 word dit sò gestel: .On die saak dus suiwer te stel moet die ke:k as instituut, beter gestel, die geinstitueerde kerk, gesien word as een deel of vorn van die kerk as organisme wat in allerlei gestalte tot openbaring kom in hierdie bedeling. Die geinstitueerde kerk sou genoem kon word die sentrale gestalte van die kerk as organisme". Hiermee ondergaan die Bybelse .ekklesia' egter 'n hetekenisverhreding omdat ènige Christelike organisasie nou 'n sigbare kerk kan wees en openbaring van die liggaam van Christus. So is dit bv. moontlik vir dic een .kerk' (Christelike kerkinstituut) om vir die ander .kerk' (Christelike staat) soms nee te sê wanneer lg. .kerk' 'n ,tendens van verabsolutering vertoon". ${ }^{: *}$ Ons het hier ook met 'n toutologiese redenering te doen want die ,kerk' word met die ,kerk' gedefinieer en daarmee word niks bepaal nie: „tot die sigbare kèrk behoort . . . die Christelike kerkinstituut ..." Andersyds mag ons ook weer nie die kerk en sy roeping vereng nie, as hy moet besef dat hy nie die ..verkondigingsprerogatief" van die Koninkryk van die hemel besit nie." as hy nie moet voorgee dat ,.hy die prerogatief besit om draer te wees van die Woord van God nie"." as hy moet weet om die Woord nie te ".monopoliseer" nie. ${ }^{23}$ Besit die kerk egter nie hierdie prerogatief nie? (Matt. 28:19, Mark. 16:15, Hand. 1:8. Joh. 2(1):21, Rom. 10:16-17). Maar dan hang alles af van wat ons onder die woordjie ,kerk' verstaan.

Indien enige ,buite-kerklike' ... selfs Christelike -- organisasie oók 'n openbaring is van die kerk van Christus, het ons m.i. dic unieke betekenis van die N.Te'ekklesia' kwytgeraak en dig ons daaraan 'n betekenisverbreiding (of-vereniging) toe wat ons nié in die N.T. vind nie. en het ons op hierdie wyse die onderskeiding ,kerk' en ,vrye (Christelike) organisasie' prysgegee.

Hierdie problematiek word na vore geroep deur die blykbaar onbruikbare onderskeiding instituut/organisme' iets wat geen Bibelse onderskeiding is nie maar wel vrug van teologies-dogmatiese besinning. Tereg beweer prof Duvenage dat dit 'n ..grootliks omstrede opvalting" is." K. Dijk het al daarop gewys dat hierdie onderskeiding onhoubaar is omdat die .kerk as instituut' óok 'n organisme is en die .kerk as organisme' ook institutêre vorms aanneem. Bavinck het die begrippe ook anders as Kuyper hanteer." Met hicrdic onderskeiding ontkom ons nouliks aan die (Roomse) dualisme van 'n Sondagkerk (instituut) en 'n Maandagkerk (organisme). Die kerk is na sy wese en lewe één.

M.i. moet ons afskeid neem van die terminologie instituut/organisme en teologiseer met die veel helderder en sprekender .... en Bybel. ser - begrippe ,kerk/Koninkryk'. Maar dan moet ons die identifikasionisme van Rome afwys (soos dic H.K. doen. Sondag 48). Treffend dat die briljante Rooms Katolieke dogmatikus, Küng, dit self ook doen,"i" al relativeer hy enigsins die wese van die kerk ten koste van sy roeping." In kort kan ons sê dat die kerk méér is as blote strydende lecir in die Koninkryk; in die kerk word ook iets gerealiseer vàn die Koninkryk. Enersyds proxluseer die Koninkryk die kerk, andersyds imtrodme'er die kerk die Koninkryk."* 


\section{KI.ERIKAI.ISTIESE KERKBEGRIP.?}

Soms word dic ampsdraers, die .clerus". gesien en bestempel as die kerk. in onderskeiding van en soms skerp teenstelling met die lidmate. die leke'. ..Is de kerk werkelijk godsvolk. dan is het onmogelijk de .herk' ooit te scheiden van de .leken'. alsof juist de leken niet in de volle zin .laos" zouden zijn". Dic woord laos beteken in die N.T. ..geen verschil himmen de gemeenschap tussen priesters (.clerici) en volk (.leken' .kerkvolk')"3" As die N.T. die hele gemeente laos (Godsvolk) noem, is dit baie opvallend dat die woord laikos (leek) geheel en al ontbreek! Eers sedert die E3 tree die onderskeid .clerus" en .leek" veral op die voorgrond.

So 'n klerikalistiese kerkbegrip kan die ware en beslissende aktiwi. teit en inisiatiewe slegs sien en vind by die ampsdraers. Die lidmaat is slegs die passiewe loehoorder' en die geciuldige .kerk'-ganger. Volgens die briewe van Paulus. veral dié aan die Korinthiers, is dit duidelik dat elke gelowige sy besondere gawes van (jod ontvang het en as sodanig moet ontplooi, en dat alle konsentrasie en sentralisasie van dié gawes in ampsdraers uitgesluit is. Dit is daarom baie opvallend dat die N.T. die wêreldlike woorde arche. limè. telos' as beskrywing van die werk van ampsdraers opsetlik vermy. ondat dit 'n outokratiese heersersposisie sou tuitdruk. In teenstelling hiermee word die woord diens" (diakonia) gebruik.". Waar in cen kerk of in een gemeente slechts ambtsdragers en niet alle gemeenteleden actief zijn. dient men zich ernstig af te vragen of hier niet met de charisma's ook de Geest wordt logelaten"."

Die kerk is dus nie dáar walar die ampsdraer is nic. Dit is nie waar dat as die predikant of ouderling gepraat het. die kirk dan gepraat het nie. 'n Ampsdraer het nie die reg om individualisties namens die kerk te pratat nie. Die kerk is nie-gelyk-aan sy ampsdraers nie. bestaan ook nie net uit ampsdraers nie. Al die gelowiges saam. die hele Godsvolk lokaal of totalal is die kerk.

\section{KOILEGIAI.ISIIESE KERKBEGRIP}

Ien van die kenmerke van die kollegialisme is Jat dic .kerk' geidentifiseer word met o.a. in kerkvergadering. In hierdie opsig dra dit "n Roomse smet. ${ }^{3}$ So hoor ons bv. Jat as in sinode of kerkraad 'n uitspraak gedoen het. dan het die kèrk gepraat. Soms word so ver gegaan en beweer dat as die moleratuur of kommissie van in kerkvergadering in verklaring uitgereik het, dan is die stem van die kerk le! dan nog bedoel as kerkierbund, dus al die gemeentes/kerke) gehoor. Dr. Z. B. l loots beweer ..dat die Ned. Cieref. Kerk nie ongereformeerd is wanneer van die kerkverband as kerk gepraal word nie". Die siening dat die sighare kerk altyd net plaaslik aan die lig tree. noem hy .. in beskouing wat beslis independentisties gekleur is"." Vir sy standpunt leroep hy hom op gereformeerde herk regkundiges maar nié. na my beste wete. op die Skrif nie. Sy siening sou wiarde gehad het indien daar geen kerk(verbande)like verskeurdheid was nic. maar waar hy nou in on. 
bybelse sin in áantal gemeentes/kerke (N.G.) kèrk nocm (enkelv.). word dic kerk(verbande)like verskeurdheid gesanksioneer en gekontinucer. en kom 'n sodanige .kerk' met die pretensie dat hy die enigste ware .kerk' is. Kollegialisme grens aan absolutisme.

Ook die Gereformeerdes is hier nie heeltemaal vry te spreek nie. In 'n boekresensie in ..Die Kerkblad" word i.v.m. interkerk(verbande) like samesprekings die vraag gestel of ..interkerklike samesprekinge nie tot die sinodale vlak heperk moet word waar dit offisieel en spesifiek gaan oor wat ons as kerke uimmekaur hou nie? As samesprekings tussen gemeentes hieroor sou gaan, moet dit onthou word dat daardie gemeentes elkeen in 'n eie kerkverband staan en dat die samesprekings uiteraard implikasies inhou wat veel breer gaan as die plaaslike kerk"." (lit die eerste sin is dit duidelik lat die woord .kerke' gebruik word in die sin van .kerkverbande'. In die tweede sin. waar die oorgang gemaak word van ,kerke' na gemeentes'. word gedink in terme van 'n ,kerk' wat uit '" aamtal gemeentes bestaun. Mag ons die ,kerk' net soek ren vind) by die sinode? Is dit nic kollegialisties nie? Is die plaaslike kerk/ gemeente nie ook vòluit kèrk nie en kan 'n (inter)kerklike gesprek nie ook plááslik offisieel gevoer word nie?

Ons kan in hierdie verband ook verwys na die náám van die (ieref. Kerk (en N.G. en N.H. Kerke) waar 'n aantal gemeentes/ kerke (mv.) in die enkelvoud , vernoem' word as ,Kerk'.

Enigsins moeiliker word die situasie as ons in die .Ouderlingformulier" lees dat met ...ê dit aan die gemeente" (ekklesia), (hristus ...sekerlik nic al die lidmate van die gemeente afsonderlik beloel (het) nic. maar heel gepas diegene wat deur die lidmate gekies is om hulle te regeer". Wat is die konnotasie van die woorde heel gepas"? Is dit identifikasionerend bedoel in die sin van ekklesia-kerkraad? As die Here Jesus gesê het: Sề dit aan die ekklesia. kan ons sề dat Sy bedoéling was: Sê dit vir die kerkraad. " Dit is opmerklik dat die H.K. hom in hierdic geval veel genuanseerder uitdruk. as ons lees dat volhardende sondaars ..by die gemeente, of die wat deur die gemeente daurvoor angewlis is, aangegee moet word" (antw. 85) (my kursivering. J. H. v. W). In sy kommentaar op art. $76 \mathrm{~K}$. (). noem ds. 1.. S. Kruger dat ..die besluit tot die afhouding van die Nagmaal dan alleen deur die kerkraad in "n offisiele vergadering geneem word (l Kor. 5:4)".37 En nou is dit juis so dat in die tuggeval van 1 Kor. 5 die hèle geméénte pertinent na vore tree (vs. 4). Riduerbos sê selfs dat Paulus hom nêrens rig tot die ampsdraers ...over de gemeente heen"."

Die kollegialistiese kerkbegrip bring ons voor die gewigtige probleemstelling: wanneer is 'n kerk vàlse kerk? Wanneer kerklike icr. goderinge gedwaal het? Maar ons mag dan nic vlotweg ,kerk' en .kerkvergadering' identifiseer nie, want is dit nic kollegialisme nie? Hicrdie vrae is nié in indepentisitiese sin bedoel nie, met relativering van die gesag van kerklike vergaderinge. (Kollegialisme is 'n neef van presbiterianisme, waar presbiters gesag voer of probeer voer los van (hristus en sy Woord om. ${ }^{\text {s4 }}$ 


\section{VOIKSKERKBE(jRIP}

Hierdie valse kerkbegrip het funeste gevolge nie alleen vir 'n juiste kerksiéning maar ook vir die kerktáák. In hierdie verband is daar twee opvallende uitwasse.

Die eerste is daardie waar die kerk en l'olk geïdentifiseer word. Hiervolgens moet iemand as lid van 'n bepaalde volk (nasie) outomaties lid wees (word) van die kerk van' daardie volk. Sodoende word die grens tussen kerk en wêreld vervaag en word die kerk in sy eintlike gestalte as kerk van Jesus Chrisus wesentlik aangetas. Ongeag die ruinese kerk- en dogmahistoriese gevolge wat hierdie siening deur die eeue geliad het. word dit noglans (soms onbewus) in mindere of meerdere mate voorgestaan deur die Herv. Kerk van Nedl.. die I uhterse Kerk van Duitsland. en ook die N.G. en Herv. Kerke ter plaatse.

Die tweede -.. en groter ... Jrogsiening is dié waar die kerk hoofsaaklik gesien word as diemsmangd ran die rolk. Selfs die kerklike eenheid moet on hierdie rele nagestreef word - nie on Gòdswille nie maar on volkswille. Die totale dienswerk van die kerk moet dan afgesten wees op die volksopbou en die kerk moet selfs sover moontlik sy stempel plaas op alle Regeringsbesluite. Die logiese konsekwensie hiervan sal wees dat die kerk se ..barmhartigheidsdiens (sal) verval tot blote filantropie of volkswelsyn. sy sendingwerk tot geestelike selfbeveiliging of bevordering van die beskawing en sy evangelisasie tot morele rehabilitasie of blote lede-werwery"."

Dit beteken egter allermins dat die kerklike lewe heilloos. ja. selfs onheilspellend vir die volkslewe hoéf te wees. Die vrugte van in gesonde kerklike lewe -- by implikasie: kerklike eenheid - sal oorval op die volksakker. maar dan is dit alles gawe van God (Matt. 6:33). Daarom is dit veel Bybelser on te spreek van 'n volkerekerk(e). waar die volk gesien word as 'n terrein waarop die Koninkryk van God moet kom en waarii die kerk gestalte moet aanneem." Die kerk staan in diens van die Koninkryk soos dit realiseer in elke volk en taal en nasie. Daarom kan ons sê: die kerk guan die volk in (Matt. 28:19). Maar ons sou die stelling ook kon omkeer en sế: die volk kom die kerk in nie hoof vir hoof nie. maar in sy uitverkorenes." Volgens die hele struk. tuur en afsonderlike dele van die N.T. werk God nie (net) op individualistiese wyse met die implementering van Sy Koninkryk nie maar .nasionalisties". Hierdie refrein klink deur tot in Openbaring 21:24-26. waar ons lees van die heerlikheid en die eer van die nasies wat in die nuwe Ierusalem ingebring word. Tereg word daarom die volkskerkgedagte afgewyys (D.C.S. van Merwe, J. C. Coetzee. W. I. Snyman. Stauffer) en vir die volkerekerke-konsepsis gekies.

\section{ABSOI.UTISTIF:SE KERKBEGRIP}

Met hierdie kerkbegrip het ek die meeste geworstel en heskou dit tewens cok as van die gevaarlikste. Met 'n abolutistiese kerkbegrip nord haloel dat die eie kerk(lerhand) anmaur word as die enigste ware kerk. Alle ander kerke/kerkverbande is dan vals of minder suiwer en 
moet gevolglik opgeroep word om by (lie eie' ware kerk (verband) aan te sluit. So 'n absolutistiese standpunt is egter suiwer Rooms. Op 25-1. 1968 het pous Paulus nog baie duidelik in 'n toespraak oor ekumenisiteit beweer dat ekumenisme vir hom niks anders is nie as 'n terugkeer van die afgeskeie broeders in die onontbeerlike gemeenskap van die enige deur Christus gewilde Kerk onder die gesag van die outentieke opvolger van Petrus. ${ }^{13}$ Hans Küng meen egter dat die Tweede Vatikaanse Kon. silie hierdie identifikasionisme en eksklusivisme afgewys het. .Ze identificeert zich dus, ondanks sommige andersluidende formuleringen. niet meer absoluut met de kerk van Christus."

On egter meer ,tuis' te kom Hierdie hele problematiek word beheers deur die beskouinge oor ware/valsc kerk, meer/minder suiwer kerk. Dit opsigself sou 'n opstel regverdig. en daarom volstaan ons met enkele stellinge wat reeds nader uitgewerk is in 'n artikel in ,.Kruispunte"."i"

(a) Ons Belydenis (veral N.G.B. art. 27) leer ons on die begrip ware/valse kerk nié in 'n swart-wit-skema te hanteer nie. Alle simplisme word deurgebreek, want al kan hierdie twee kerke .,maklik geken" word. moet ons tog ...met ywer en versigtigheid" hierdie "onderskeiding" aanwend (kursivering van my. J. H. v. W.) Polman wys ook in sy groot studie oor die N.(i.B. daarop dat èlke kerk in ,eigen hoezem" "met de valse kerk te strijden (heeft) en door haar bezet (kan) worden"." ja, ons moet veg teen die valse kerk .die binnendringen wil en hinmen is" v. W).

(b) Calvyn het ons al geleer hoe moeilik dit is om die valse kerk te lokaliseer. Hoewel hy van die Roomse Kerk kon sề dal ..iedere vergadering en ook het gehele lichaam van het pausdon de wellige gedaante van een kerk mist" (het 'n .kerk' vir Calvyn uit gemeentes - vergaderinge - bestaan?') gee hy log toe dat ons nie kan loën nie ..dat er bij hen kerken zijn" "Bavinck het al gesề dat die ware kerk nooil daar sou gewees het nic as die dric kenmerke absoluut gegeld het."

(c) Calvyn het nie net die (jeref. Kerk(groep) as ware kerk gesien nie ..Zo valt voor Calvijn de ware kerk niet samen met de (jereformeerle kerk. De Engelse. episkopaalse kerk. de I utherse. zelfs de gemeenten der Waldenzen en Bohemers worden als ware kerken erkend". Volgens art. 29 N.(j.B. word onder ware kerk verstaan èlke kerk ..die aan de gestelde kenmerken voldoet. Daaronder worden alle kerken der Reformatie begrepen. al is er verschil in zuiverheid zowel in leer als in liturgie".

(d) Polman meen dat ..wie de tegenstelling ware e'n valse Kerk vervangt door of verklaart in de zin van de onderscheiding meer of minder zuivere Kerken heeft de historische betekenis van de woorden der Belijdenis losgelaten en schrijft hatar een andere mening toe dan zij bedoelt" 
In hierdic verband kom ons kerkorde ter sprake en ontstaan die vraag in hoeverre daar rekening gehou word met ander kerke (verbande) buite die (jeref. Kerke. Besit die Kerkorde dalk 'n eksklusivistiese kerkbegrip? Ons dink onmiddelik aan art. 9: ..Predikers wat uit ander kerke of een of ander sekte aansluit ....". waar wèl die bestaan van ander kerke" erken word (naar dan is dit waarskynlik ook die enigste plek). Wat is egter die konnotasie van die begrip ander kerk"? In art. 61. wat handel oor die toelating tot die Nagmaal. kom die begrip ander kerke' (ook voor, maar dan (in 'n latere edisie) nader gepresiseer as ...ander kerke (van dieselfde kerkverband)". Sou dit ook nie Skriftuurliker wees on te spreek van .Die Geref. Kerkè in S.A. nie? - - eerder as ,Geref. Kerkverband'it Treffend dat nog al die jare die inleidende woord op die Dordtse Leerreëls - tereg - lui: ..Die beslissing van die nasionale sinode van die Gereformeerde Kerkè van die Verenigde Nederlande . . . ." Dit is seker nie slègs omdat die Dordtse Sinode in ckumeniese" sinode was nie -

\section{KERKBEGRIP VAN ONS KERKORDE}

Hiermee word slegs in paar kort flitsende grepe gemaak. Ek pretendeer niks en konkludeer niks - analiseer net. Al wat eie is aan voorlopigheid is eie aan hierdie analise. Hier moet nog veel teologies. en veral in historiese perspektief. deurgepraat word.

1. Die woord .kerk' word gebruik in die sin van .lokale kerk' (vgl. art1. 1. 4. 7, 10. 11. 14. 15. 17. 20, 27, 33, 41. 42. 44. 61. 62. (71) 75 (77). (79). (80), 84, 86).

2. Dit skyn nie asof .kerk' as sinoniem vir .gemeente' gebruik word nie. Beide woorde kom dikwels blykbaar onderskeidend voor in dieselfde artikel (vgl. 23, 28. 44, 59, 71, 77) (vgl. egter 82, 83).

3. Soms skyn dit asof daar sodanig tussen .kerk en gemeente onderskei word dat .kerk gemeente plus ampsdraers, en gemeente kerk minus ampsdraers is (vgl. art. 16. 22, 23. 25, 55, 59, 70), 71, 77. 82. 83). Soms lyk dit asof gemeente'- aktuele byeenkons (4. 7(1)): erecliens" word pertinent genoem in 0.a. 56 en 64.

4. Die meervoud van .kerk' is .kerke' (artt. 4, 7, 19, 28, 37. 41. 44. 51. 66. 67, 69, 84).

5. Sonis word die hegrip .kerk' as versamelnaam gebruik vir 'n alanlal kerke $(5,59,61,71,85,86)$ (vgl. ook 77. 79. 80)).

6. Nêrens kon die meervoud, gemeentes' voor nie.

7. Daar word soms gespreck van .kerkverband' (o.e. 5, 201, 61).

8 . Een maal kom dit voor dat van in meerdere vergadering (hlassis) gesê word dat dit in vergadering van naburige kerke is $(41)$ "

9. O. a. vyf keer vind ons die begrip ander kerk(e)' (9, 10, 15. 61 . 84). Slegs cen keer (9), dui dit op "n ander kerk(verband) buite die Geref. Kerke, terwyl dit die ander kere op die ,eic' kerk(verband) sien. 
IV. WAAROM"?

Daar sou seker baie redes aangevoer kon word vir al die verwarring t.o.v. die kerkbegrip. Ek noen 'n paar voor-die-hand-liggende redes, om dan by een meer uitvoerig stil te staan.

1. Geen Bybelse oriëntasie.

Weinig het werklik in die lig van die Woord van Goxl (en ons Belydenis) 'n (eksegetiese) studie gemaak van die ekklesia' van Gol. Vandaar dat ons so maklik op sleeptou geneen word deur die daaglikse woordgebruik. Daar is by min van ons eksegetiese diepgang.

2. Ongedissiplineerde woordgebruik.

Dit is duidelik dat daar by ons baic weinig selfdissipline is t.o.v. die gebruik van die woord ,kerk' of .gemeente'. Dit word oral onnalenkend ingestop.

3. ,Kerk’ en ,gemeente'.

Omdat ons nie helderheid het oor die konnotasie van die begrippe ,kerk' en gemeente' nie. opereer ons stceds met die onskriftuurlike siening dat ' $\mathrm{n}$,kerk' uit 'n aantal gemeentes' bestaan. In ons Belydenis word beide woorde tereg as sinonieme gebruik. Dis 'n vraag of ons Kerkorde in hierdie opsig konsekwent is. (Ons moet steeds onthou dat slègs die woord gemeente' (ekklesia) direk uit die Skrif stam en dat ,kerk' (kuriake) 'n latere, teologiese' toevoeging is. wat ons nie noodwendig dáárom op Barthiaanse wyse hoef te skrap nie solank ons dit maar korrek gebruik!

4. Kerklike verskeurdheid.

Kerklike verskeurdheid is een van dic grootste - indien nie dié grootste - redes van al die verwarring op hierdie gebied. In plaas daarvan dat ons die Bybelse woordgebruik behou het. het ons dié losgelaat en daarmee by haas enige moonilikheid uitgekom. Dit kan nou eenmaal nie ontveins word nie dat wie die Skriftuurlike kerkbegrip laat inplons in die huidige kerkelike situasie, met 'n spanningsvolle - - soms ,gevaar. like' - situasie te doen kry. Dit sou nie oordrewe wees nie om te beweer dat deur die Bybelse kerkbegrip, ons absolutistiese kerkverbandelike strukture heilsaam versag word.

In hierdie verband het die kerkname verwoestend gewerk. Ons hoor nie alleen van .my kerk' en ,jou gemeente' nie (terwyl dit Gou s'n is in Jesus Christus, I Thess. 2:14), maar ook ,moederkerk' en dogterkerk' (terwyl ..Jerusalem daarbo" ons moeder is. Gal. 4:26). (Ons hoor van Roomse Kerk, Griekse Kerk, Lutherse, Anglikaanse, Metodiste. Presbitesiaanse, Baptiste, N.G. Kerk. Herv. Kerk, Geref. Kerk. Verdere skeuringe had ten gevolg lànger name. Sommige vernoem die kerk na 'n dogma (Baptiste). sommige i.v.m. kerkregeringe (Presbiteriane. Kongregasionaliste), sommige o.a. i.v.m. 'n hervormingsdaad (N.(j.K.. H.K.. G.K.), sommige na mense (l.utherse Kerk; vgl. . (alvinistiese Kerk' en Paul Kruger Kerk(gebou?) ).

Wat moet ons van dit alles sê!? Of beter: Wat sê die Skrif daarvan'? 
Ekklesia' is volgens die N.T. altyd vergaderinge van Gend in Jesus ('hrisuss (1 Thess. 2:14. (ial. 1:22). Die kerk word dan b.v. vernoem' na die plek waar hy te vind is: soms is dit 'n stad: Thessalonika (l Thess. 1:1). Korinthe (1 Kor. 1:2), Laodicéa (Kol. 4:16); soms weer in landstreck: Asië (1 Kor. 16:19). Galasië (1 Kor. 16:1). Marcedònië (11 Kor. 8:1). Judea (1 Thess. 2:14).

As die Korinthiese gemeente wil opdecl in 'n Appolos- en Cefas- en Paulus- en Christusgroep. is die Apostel se oordeel striemend: ..Is (hristus verdeel?' Is Paulus miskien vir julle gekruisig? (Of is julle in die naam van Paulus gedoop?" (1 Kor. 1:13). En log hèt dit in dic loop van die geskiedenis gebeur! Ons dink bv. aan die niees konkrete voorbeeld van ,Lutherse Kerk'. 'n contradictio in terminis. (Luther het hom heftig daarteen verset dat sy naanı aan in kerknaam gekoppel word). omdat mens nie tegelyk aan l.utiet en (jov kan behoort nie. Gelukkig dat ons daarvan bewaar gebly het om van 'n .Calvynse Kerk' te praat al kom die ongelukkige uitdrukking .Calvinistiese Kerk' soms nog voor.

Die kerk is na sy wese omernombar -- die Skrif sê net telkens wailr die ekklesia van (jod in Christus te vind is - en watter versierende byname ook al uitgedink kan word, hulle sal net so telkens voor die Bybelse kerknaam en -begrip moet swig. Die ekklesia is ekklesia van (iod' of nou en dan eckklesia van Christus' (Rom. 16:10) (toutologies: kirk van (hristus) en niks anders nie.

Vanuit die Skrif besien. is daar dus bepaalde kritiek te lewer op dic naam ..Dic Gereformeerde kerk in Suid-Afrika". Daar is geen probleem met die ..in Suid.Afrika" nie, mar met ... Gereformeerde" en ..Kerk". Hier word tog 'n aantal kerke/gemeentes .kerk' (enkelv.) genoem, iets wat ons nié in die Skrif vind nie. Voorts kan daar vanuit I Kor. 1:12-13 transendentale kritiek gelewer word op die bynaam ,Gereformeerde'. Natuurlik mag ons I kor. I nie ongenuanscerd toepas op die kerklike situasie van vandag nie omdat die N.T. nog vóór die verskeurde toestand staan. Paulus had ook nie te doen met interkerkierhandelike groeperinge nie maar met in intra-kerklike situasie. met groeperinge binne die één Korinthiesc kerk. Tog lyk dit my gesien ook in dic lig van die .Pauliniese kerkbeskouing - dat ons die teks nié forseer nie as ons beweer dal indien Paulus groeperinge bimme die e'en gemeente afgekeur het. hy dit de's te meer sou gedoen het war geme'entes hulle afsonderlik teenoor mekar sou opgestel en afgegroepeer het.

Ons sou op dic naam . (iereformecrde' ook immunemte kritick kon lewer. Dit is $n l$. 'n vraag of die vorm-materie-leer (selfs via l atyn) nie hier sy kop uitsteek nie: (iere-form-eerde' (vgl. .Her-vorm-de') met eensydige klem op die worm?. Het dit nie juis in die Reformasie on die inhoúdelike gegaan nie?") (Ons sou kon wys op die passiewe element en verlede tyd i.(ie-reformeer-de'). sodat dit altyd orent gehou moet word deur voortdurend te herinner dan die aktuele. dinamiese. met die tyd saambewegend .Reformerende' kerk. Hierdie twee elemente. die slaticse en dimamiese. mas nie in die kerk se roeping. en ook nie in die kerk se náám teen mekaar uitgespeel word nic. "n Staliese herk 
verval in ortodoksisme en stagnasie; 'n bloot dinamiese kerk vervlugtig in aktualisme en eksistensialisme.

Baie van hierdie probleme sou egter maklik verdwyn as daar net één .kerk' op aarde was. En ons sal moeilik kan beweer dat dit nie die Skriftuurlike kerkperspektief is nic (veral Joh. 17:21, Efes. 4:4-6). Daar bestaan ' $n$ duisend menings oor hoe hierdie ekumeniese probleem opgelos kan word. Enersyds is daar by sommige 'n totale afkeer. andersyds 'n positiewe aanjak, en dit wissel weer van 'n koöperatiewe tot 'n korporatiewe eenheidsstrewe. In hierdie verhand sal o.a. die Byhelse' kerkbegrip l'an deurslaggewende betekenis wees. ${ }^{j}$

Soveel is egter duidelik dat die kerk as volk van Gool, as liggaam van Christus, as bouwerk van die Heilige (jees één is. omdat dit nie anders kàn wees nie. Die ekumeniese roeping bestaan derhalwe daarin dat die ,kerk' tot uitdrukking moet bring wat hy is."

J. H. van Wyk.

(jelewer voor (j.T.V. Witwatersrand $(13$ Mei 1968) en (i.T.V. Pretoria (27 Mei 1968).

\section{VERWISINGS}

1. in „Eeufees te Rustenberg", Potchefstroom. 1959. p. 140 (Voortaan slegs ..Ecufces").

2. F. J. Pop. ..Bijbelse Woorden en hun (jeheim" 1. 's-Ciravenhage. 1957. p. 116.

3. Hans Küng. ..De Kerk”. Hilversum-Antwerpen, 1967, p. 95.

4. Contra Pop a.w. p.p. 112, 113,116. So by W. J. Snyman. ..Eeufees", p. 140.

5. Vgl. Herman Ridderbos, ..De Komst van het Koninkryk", Kok-Kampen.

1950, pp. 288-320 (veral 309), en ..Paulus: Ontwerp van zijn Theologie". Kok-Kampen, 1966, p. 366; W. J. Snyman. „Dic Gebruik van die woord .kerk' in die Nuwe Testament", Potchefstroom, 1949; (Voortaan ..Kerkbegrip") K. L. Schmidt: ekklesia' in Th. W.N.T.; Küng. a.W. p. 93v.; ,De Nieuwe Katechismus", Hilversum-Antuerpen. 1966, p. 595.

6. Küng. a.K. p. 99

7. Idem, p. $1(0)$.

8. Dit is seker nie moontlik dat in lidmaat wat met attestasie uit in gemeente vertrek in wese kerkloos' is nie : ..Handleiding by die Kerkorde van die (jereformeerde Kerk in Suid-Alrika" (verskillende outeurs), Pro RegePotchefstroom, 1966. p. 490. (Vootlaan ..Handleiding").

9. Snyman, „Kerkbegrip”. p. 5.

10. ..Paulus", p. 537. Die fyn onderskeiding wat ons vandag maak lussen .erediens' en gemeentelike samekoms kan seker moeilik teruggevind word in die N.T.

II. Idem. p. 366. Vgl. Küng a.w. p. 98.

12. Küng a.w. p. 149.

13. Idem. p. 151.

14. J. A. Heyns. ..Klagtebock teen die Kerk en sy menee". Sacum. Bloemfon. tein (ongedateer) p.p. 10-11. Vgl. Küng a.w. p. 13. ..Dit is een abstract onderscheid". Küng. p. 370.

15. ..Almanak van Die Gereformeerde Kerk in Suid-Afrika", Potchefstroom. 1966. p. 11.

16. A. D. R. Polman, ..Onze Nederlandsche Cieloofsbelijdenis" III WeverFrancker. (ongedateerd), p. 275. (Voortaan ..N.(i.B.").

16a $\mathrm{Vgl}$. J. H. P, van Rooyen, ..Kerk en Staat" ("n vergelyhing lussen Kuyper en van Ruler) (ironingen 1928. p. 113-148. 
17. S. C. W. Duvenhage. ..Kerk, Volk en Jeug" I. Heijnis-Zaandijk, (1962), p.p. 4()$-62$.

18. Idem. p. 291. So op p.p. 55. 63. 247. 248. 284. 285

19. Idem, p. 274

20. Idem, p. 291 .

21. Idem. p. 287.

22. Idem. p. 245 .

23. Idem. p. 279.

24. Idem. p. 63, voelnota.

25. Vgl. R. H. Bremmer, ..Herman Bavinck als Dogmatikus", Kok-Kampen, 1961. p. 282.

26. Küng a.k. p. 111

27. Idem. p. 112 .

28. W. Lee. ..Het Koninkrijk en de Gemeente". in: ..Leven en (jetuigenis", jg. 23. no. 3; aangehaal deur l. Flood. ..In Dieselfde Spore". Potchef stroom. (1964). p. 76. Vgl. ook Ridderbos. .Koninkryk". a.4. p. 307. en Tjaart van der Walt. .Die Koninkryk van (jod - Naby!", Kok-Kampen. (1962), p. 33.

29. Met erkenning teenoor dr. B. Spoclstra. Wat my oe vir hierdie kerkbegrip geopen het. In samehang met die klerikalistiese kerkbegrip (waar kerk en ampsdraer vereenselwig "word) en die kollegialistiese kerkbegrip (waar kerk en kerkvergadering lereenselwig word). sou ook genoem kon word 'n .independentistiese kerkhegrip' (waar kelk en individuele gelowige vereenseluig word). Hierdic klerikalistiese opvatling is tamlik oud: ..Waar de bisschop zich vertoont. moet ok het volk zijn zoals waar Jezus Christus is de katolieke kerk is" (lgnatius van Antiochic. 110). Küng a.W. p. 342.

30. Kiing, a.w. p. 145

31. ldem, pp. 2(1) 207, 215, 216

32. ldem. p. 217

33. Tereg ...Handleiding". p. 20.

34. .. Die Kerkbode". 26 Julic 1967. p. 124. Vgl. (lereg) (j. P. 1. van der Linde ..Die (irondheginsels van die Presbiteriale Kerkregeringsstelsel". Pro RegePotchefstroom, 1965. p. 157, voctnoot 17.

35. „.Dic Kerkblad". I Mei 1968. p. 11

36. Vgl. K. S. van Wyk de Vries. ..Deur Bloed Gekoop". Pro Rege-Polchefstroom. 1957. p. 193: ..As hy nog nie luister nice sê dit dan aan die gemeente dit is dic kerk raad."

Vgl. ook W. 1. de Klerk. ..Wending". Pro Rege-Potchefstroon. 1964. p. 28 : ..In dic wykskring het ons log rok dic openbaring van die liggaam van Christus soos die huisgemeentes van Aquila en Priscilla". Kan ons sommer vlotweg in wykshring in 'n gemechlo identifiseer met 'n huisgemeente?

37. ..Handleiding". p. 451 .

38. ..Paulus". p. 529 .

$38 \mathrm{a} \mathrm{Vgl.} \mathrm{W.} \mathrm{D.} \mathrm{Jonker:} \mathrm{..Fgte} \mathrm{onderwerping} \mathrm{en} \mathrm{gehoorsaamheid} \mathrm{kom}$ in dic kerk alleen aan die Woord lan (iod toe. nic aan die ampsdraers of hulle bepalinge as sodanig nie" (O) die Regering van Christus in Sy Kerk", (Unisa). 1965. p. 11.

39. $\mathrm{Vgl}$...Kruispunte". jg. 2. no. 2. pp 12-15

40. A. J. Venter. ..Kerk en Belydenis". Potchefstroom. pp. $21-2$.

41. Vgl. W. D. Jonker. ..Aandag vir dic Kerk". Potchefstroom. p. 51.

42. J. C. Coetzec. .Volk en Ciodstolk in dic Nume Tentament". Pro RegePolchelstroom. 1965. pp. 308. 319. 321. passim.

43. in .. (iereformeerd Weehblad". je 23. no. 37. 8 11aart 1968. ค. 255

44. Küng. a. 1 . p. 326: so p. 202.

45. Jg. 4. no. 4. pp.l-8.

46. .N.C, B.". a.w. n. 378 .

47. Idem. p. 380. Vel. Bremner a.4 $p$.64. So by $S$. J. Ian der Walt in . (ielonfsleer en Sedelect". Kaapulad. (ongedateerd). p. 178.

18. Vgl. W. Nijenhuis. .(alisus (ecuntenicus". s-llage-Nijhoff. 1949: D)

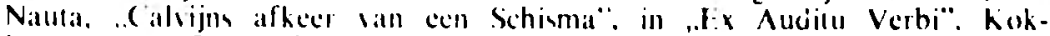
Kampen. 1965. pp 1.31-156. 
49. „Institusie”, Meinema-Delft, IV. 2, 12.

50. "Gereformeerde Dogmatiek" IV (4e). Kok-Kampen. 1930. p. 303. Vgl. Bremmer, a.w. pp.282-283. Vgl die kritick van $K$ iing op die Roomse vier kenmerke- en die Relormatoriese twee kenmerke- leer: ..Wat zou hel een kerk baten als ze de Schrift ,hecft' en bij haar toch niet de macht en de kracht van het evangelie gehoord wordt; als zij de sacrenenten .heel't' matr deze door bijgeloof en afgoderij onverwoekerd zijn; als haar eenheid. heiligheid katholociteit en apostoliciteit institutioneel stevig gegrondvest en zichbaar gemaakt zijn en deze instituten toch uitgeholde vormen zijn zonder leven- Dus niet het formele voor-handen-zijn van bepaalde eigenschappen. maar het gebruik en de voltrekking ervan doorslaggevend . . a.w. 309.

51. Polman. ..N.G.B.”, a.u. p. 234. Vgl. Polman in ... hristelijke Encyclopedie IV, Kok-Kampen. 1959. p. 198.Calvyn word soms (Iereg) in .oorgangsfiguur' genoem. Dit beteken o.a. dat sy ekklesiologiese standpunt nie ongenuanseerd en simplisties op die kerklike siluasie van vandag toegepas mag word nie. Maar dit beteken nié dat Calvyn vir vandag nıks te sê het nie en op non-aktiwiteit geplaas kan word.

52. Polman, ..N.G.B.", a.w. p. 362.

53. Idem, p. 231 .

54. ,.Handleiding", p. 15.

55. ..Kerkorde van dic Cereformeerde Kerk in Suid-Afrika". Potchelstroom. 1965.

55a Vgl:: "... is dit juister om van meerdere vergaderinge te praal as semekomste van me'er kerkrade... .", Van der Linde. a.w. p. 142; en: „Omdat in klassikale vergadering primêr 'n vergadering van kerkrade is . . . ", .Handlciding", a.k. pp.261-262.

56. Contra die bewering dal die N.G.K. Kaapstad .dic moeder van ons almial is": H. C. Hopkins. .Dic Moeder van ons almal". Kaapstad-Pretoria. (ongedaterd). Die N.T'. ken nie so 'n maternalisme nic.

57. Vgl. „Uit een bloed”, Pro Rege-Potchefstroom, 1961, p. 43; W. D. Jonker. ..Aandag" a.W. p. 22; W. J. Snyman. ,Eeufees", p. 140; W. J. Snyman. " Die kerk van Christus in Afrika”, in "Koers", ig. 33, no. 3, Des. 1965. p. 237.

58. Vgl. Calvyn: .. Indien wij erop gesteld zijn om onder ons de cenheid en de vrede te doen blocien, laten wij dan de eenheid veeleer in de leer en de gevoelens zoeken. dan ons eigenwijs vast te bijten op de nauukeurige overeenkomst in de vormen van de eredienst" by $\mathbf{H}$. Volten. "Rondom het Belijden der Kerk", Kok-Kampen, 1962. p. 197, (voetnota).

59. Vgl. A. A. van Ruler in ..Kerk en Theologie", jg. 18. no. 4, Okt. 1967. p. 331: ,.De oecemenische vraag is in de kern een kerkelijke vraag en de kerkelijke vraag is in de kern ec, institulêre vraag".

60. W. J. Snyman in ..Handelinge van die ses-en-dertigste Sinodale Vergadering van die Gereformeerde Kerk in Suid-Afraka", Potchefstroom. 1967 p. 379; vgl. Polman in ..N.(i.B." p. 380) Küng a.w. p. 328, 329. Hierdic (nog nie ten volle gerealiseerde) werklikheid mag nie, met verbygan v'on dic konkresc kerklike verskewrdheid, onproblemalies voorgestel word nie, ,Handleiding”, p. 20; vgl. pp. 177, 181, 321- 323. 